\title{
Skills Society and Cognition Policies in the Formation of Teachers
}

\author{
Rosimeri de Oliveira Dias ${ }^{1}$ \\ Universidade do Estado do Rio de Janeiro, São Gonçalo-RJ, Brazil \\ Virgínia Kastrup \\ Universidade Federal do Rio de Janeiro, Rio de Janeiro-RJ, Brazil
}

\begin{abstract}
This study analyzes the formation of teachers and its relationships with the skills society. According to Sennett the skills society appears in the capitalism mutations and brings within it the notion of portable potential ability, stimulating the workers, so they can cope with acceleration and the short-term of information. The investigation distinguishes two cognition policies in the formation of teachers: (in)formation and (trans)formation, which co-exist. The first is based on information and connects knowing with the transmission and processing of symbolic representations. The second is grounded in experience and highlights the inseparable relationship between knowledge and invention. The study suggests that the processes which reduce formation to training and information, aiming for the development of abilities and competences, consider formation as the acquisition of knowledge ready to be consumed. In another direction, training is an inventive process, which is based on problematization and the knowledge construction experience.
\end{abstract}

Keywords: teacher formation, cognition, policy making

\section{Sociedade da Capacitação e Políticas de Cognição na Formação de Professores}

\begin{abstract}
Resumo: O objetivo deste estudo é discutir o problema da formação de professores no contexto do novo capitalismo e da cultura da sociedade da capacitação. Tal sociedade aparece nas mutações do capitalismo e traz consigo a noção de aptidão potencial portátil, estimulando que os trabalhadores se adaptem à aceleração e ao curto prazo da informação. A investigação distingue duas políticas de cognição na formação de professores: (in)formação e (trans)formação, que coexistem. A primeira é apoiada na informação e vincula conhecer à transmissão e processamento de representações simbólicas. A segunda é pautada na experiência e aponta a relação indissociável entre conhecimento e invenção. O estudo aponta que os processos de formação que a reduzem à capacitação e à informação, visando ao desenvolvimento de habilidades e competências, consideram a formação como aquisição de conhecimentos prontos para ser consumidos. Em outra direção, formação é um processo inventivo, que se orienta na problematização e na experiência de construção do conhecimento.
\end{abstract}

Palavras-chave: formação de professores, cognição, formulação de políticas

\section{Sociedad de la Capacitación y Políticas de Cognición en la Formación de Profesores}

\begin{abstract}
Resumen: La finalidad del estudio es discutir el problema de la formación de profesores y sus relaciones con la sociedad de capacitación. Esa sociedad de capacitación aparece en las mutaciones del capitalismo y trae consigo la noción de aptitud potencial portátil, estimulando que trabajadores se adapten a aceleración y al corto plazo de la información. La investigación distingue dos políticas de cognición en la formación de profesores: (in)formación y (tras)formación, que coexisten. La primera se apoya en la información y vincula conocer a la transmisión y el procesamiento de representaciones simbólicas. La segunda se pauta en la experiencia y demarca la relación indisociable entre conocimiento e invención. El estudio señala que procesos de formación que la reducen a la capacitación y a la información, con vistas al desarrollo de habilidades y competencias, consideran la formación como adquisición de conocimientos listos para ser consumidos. En otra dirección, la formación es un proceso inventivo, hacia la dirección de problematización y de experiencia de construcción del conocimiento.
\end{abstract}

Palabras clave: formación de profesores, cognición, formulación de políticas

The formation of teachers brings with it, in an explicit or implicit way, a concept of cognition and learning. The cognition studies field offers a set of distinct theoretical and, at times, divergent approaches, that configure different ways to guide the formation. Computational cognitivism (Fodor, 1983), based on the representation model and on the information theory, and radical constructivism (Kastrup, 1999; Maturana \& Varela, 2002), which defines knowledge as a

\footnotetext{
1 Correspondence address:

Rosimeri de Oliveira Dias. Faculdade de Formação de Professores. Universidade do Estado do Rio de Janeiro. Rua Francisco Portela, 1470, Patronato. CEP 24435-005. São Gonçalo-RJ, Brazil. E-mail: rosimeri.dias@uol.com.br
}

process of creating oneself and the world, are two current and divergent approaches. For computational cognitivism, cognition is an intentional relationship between a subject and an object. In this, the understanding of cognition as information processing prevails. The functioning of human cognition is equivalent to the operation of the computer. The system receives inputs, performs processing by logical rules and transforms them into outputs. In cognitivism, learning is considered to be a process of problem solving.

In the tradition of the constructivism of Piaget (1978), radical constructivism of Maturana and Varela (2002) proposes that subject and object are co-engendered by the action, i.e., by concrete cognitive practices. Accordingly, subjects 
and objects are emergent effects, and not the precondition of cognitive activity. With respect to learning, Varela (n.d.) states that the most important thing in this process is not the solving of problems, but the invention of problems. With the enaction approach, the author proposes a concept of action that is not synonymous with behavior and that does not eliminate the dimension of experience, but includes it. The most important experience is the experience of probematization, developed through the concept of disruption or breakdown. The environment does not transmit information, but generates disruptions.

The concept of "disruption" or "breakdown" is related to the moment of the invention of problems, which is a crack, a shock, a bifurcation in the habitual recognitory flow. The concept of "breakdown" is essential in arguing that no prior world exists, nor pre-existing subject. The self and the world are mutually and inseparably co-engendered by the action. They are, in turn, immersed in a permanent transformation process. For though they are configured as forms, these remain subject to further disruption, which forces their reinvention. (Kastrup, 2005, p. 1276)

The approach of enaction is a fundamental reference for the definition of cognition as a process of inventing oneself and the world. According to the inventive cognition approach (Kastrup, 1999), the invention is not one more psychological process, but a way to place the problem of cognition. According to this approach, it is an inventive perception, of an inventive memory and of inventive learning. Inventive learning is not reduced to a process of problem solving, but includes the invention of problems; it is not defined as a process of adaptation to a pre-existing world, but has the dimension of invention of the world itself (Kastrup, 2001).

Another point which is of particular importance in the discussion about the formation of teachers in the contemporary world is that invention is not synonymous with creativity. Studies regarding creativity arise in the psychological literature from the 1950s, with Guilford (1975). They were motivated by the demands of the American society with the space race, industry and advertising and generated a set of technologies for education and business administration. What is important to note is that research into creativity is inseparable from an instrumental perspective. It is an ability and a performance and is always encountered in the service of problem solving, acting as a factor of divergence from standard solutions (Kastrup, 1999).

Conversely, we believe that the formation of teachers should be understood broadly, including the social and political dimension of the education. In the contemporaneity, this needs to be discussed within the frameworks of new capitalism and of the culture of the skills society (Dias, 2011). Therefore, the aim of this study is to discuss the problem of the formation of teachers in the context of new capitalism and the culture of the skills society. From an analysis of the skills society, as proposed by Rifkin (2001) and Sennett (2006), this study seeks to identify and distinguish two trends in the formation processes: a hegemonic trend that, as we will try to show, is governed by computational cognitivism, and a trend that seeks to follow alternative pathways for the formation, based on the approach of enaction and on the inventive learning concept. Our horizon is the understanding of the formation as continuous learning, which can reverse the trend which is still the more common, in which the teacher occupies the place of transmission of knowledge. Besides the distinction between invention and creativity, which we have already established, the concept of cognitive policy will also help us make a distinction between these two orientations, which can sometimes seem tenuous in view of the valorization of new information, flexibility and the continuous adaptation by new capitalism.

We will also seek to develop the idea that to form teachers is to configure a policy of cognition (Kastrup, Tedesco, \& Passos, 2008). This concept aims to show that the problem of knowing is not reduced to its theoretical definition or to the debate about the models or paradigms that we use to understand it. The problem of knowing involves a position in relation the world and to oneself, an attitude, an ethos. Thinking in this way, to identify cognition with the model of information processing or bring it close to a process of invention of oneself and of the world is not just a theoretical divergence, but also an ethical and political distinction.

\section{Skills Society}

Sennett (2006) defines the skills society by the presence of flows of information, passwords and codes, and constant modifications of the work and of the workers in a general way, which applies to educators. According to the logic of the skills society it is necessary to continuously acquire skills that provide a base for an accelerated and short-term relationship, present in this way of managing labor relations and life itself. Such a society is understood through the notion of portable potential abilities, which dominate in business, in the school and in life. The need arises to produce subjectivity that is able to cope with a constant and rapid mutation, which, at the same time, does not attach itself to experience or to the long-term. The skills society is based on the company and makes its operation and its dependence on how the market reverberates in society. The notion of the skills society brings with it three themes: work, talent and consumption. Such topics engender political attitudes, performances and specific characteristics.

The skills society feeds on intellectual capital. Its form and strength reside in concepts, in ideas and in images. Value is not found in physical capital anymore "but rather in human imagination and creativity. Intellectual capital, it should be pointed out, is rarely exchanged, instead, it is closely held by the suppliers and leased or licensed to other parties for their limited use" (Rifkin, 2001, p. 4). The logic of the skills society is thus included in the connectionist leasing of the information. Workers, permanently in a state of training, 
acquire skills that rapidly go into disuse. Thus, they need permanent training, which allows access to the network only to make the information circulate. Here we analyze some effects arising from the logic of training, which are perpetuated in the disposable way of production of subjectivity useful to the logic of the current market. As Sennett affirms (2006), contemporary subjectivity is

oriented to the short-term, focused on potential ability, and willing to abandon past experiences can only be found in unusual sorts of humans beings. Most people are not like this, they need a sustaining life narrative; they take pride in being good at something specific and they value the experiences they have lived through. The cultural ideal required in new institutions thus damages many of the people who inhabit them. (p. 14-15)

One of the elements valued by the skills society is experience, where reference to time and duration should be analyzed. For Benjamin (1996, 2002) and Larrosa (2004), there is experience when something passes us and transforms us. Experience requires a long time to accept problematization and the resonances that it generates. In other words, in order not to be something just to be consumed, it requires duration, immersion and concentrated attention. In turn, the culture of new capitalism values experience for its acceleration and ecstasy, and not for its slow temporality. Experience is short-term entertainment for incessant consumption. Thus, it captures the experience mercantilizing it, making it the last stage of the merchandise (Pelbart, 2003).

In a turbulent and ambiguous context, the logic of the skills society penetrates the world of formation, projecting, in life and in work, adults who follow the ideal modes of cognitive functioning created by the current market. In order to adapt to such modes of functioning, adults buy their access in the endless courses taken throughout their lives, which do not necessarily guarantee good results. Thus, some questions arise: What type of training is new capitalism indicating? How can the commoditization of experience be resisted?

\section{Mutations of Capitalism}

In diverse ways, many authors deal with the transformations of capitalism, including Guattari (1981), Lazzarato (2006), Passeti (2002), Pelbart (2003), Rifkin (2001) and Sennett $(2005,2006)$. Some limited themselves to economic, social and political analyzes, others articulate these with the production of subjectivity. What arouse our interest are the formation processes of subjectivities generated in these mutations, which directly influence the field of teacher formation.

Pelbart examined how capitalism penetrates life, claiming that he won the battle to integrate intellectual activity into the productive process. In tracing this diagnosis, the author explains that capitalism liberates itself from its industrial form, assuming a relationship of post-industrial production, of services. It "formats fewer processes of formal elaboration, semiotic codes, which exercises its performative action on the cognitive work" (p. 94). This work is incalculable. Capitalism operates today in the networks subordinate to computers, allowing the integration of intellectual work and, at the same time, through expropriation of its ability to produce meaning, reducing knowledge to a mere commodity in the complex production process. Faced with a network society, new forms of control are forged. The regime of capital operates in the order of desire, affections and experience understood as entertainment.

The analysis of Guattari (1981) and Lazzarato (2006) regarding the current capitalism helps to think of the game produced in the quotidian of life and its effects on the field of teacher formation. Guattari (1981) states:

capital is not an abstract category, it is a semiotic operator in the service of certain social formations. Its function is to assume the registration, the regulation, the overcodification of the formations of powers related to the developed industrial societies, the relationships of force, and the flows relative to the set of economic powers of the planet. [...] A true measurement of the powers could only be based on modes of semiotization, in direct connection with formations of power and productive assemblages (both material and semiotic), suitably located in social coordination. (p. 191-192)

Lazzarato (2006) said that, unlike the factory, the company today produces not only commodities, but a world. What is sold in a globalized society is the image of a single world that is controlled by the logic of the company. In contrast, this determines a reduction of the open creation of other possible worlds. The influence and effects that the culture of new capitalism and the skills society exercise on the formation of teachers appear through the excess of production, excess of information and lack of time. The different techniques of coercion that operate and construct problematization devices for the modes of subjectivity in the formation of teachers should be identified.

Rifkin (2001) states that in the course of the twentieth century a new form of capitalism has been gestating and is now poised to overtake industrial capitalism, in which commercial relationships were governed by material goods and in the relationships of ownership. Today capitalism increasingly transforms the cultural resources into experience, understood as entertainment. For Rifkin, in the new culture of capitalism, the commercial relationships are governed by access - to the commodities, images, information - where the limits and frontiers become indistinguishable and all that is solid melts in the symbols, in the web, in the connectivity, and in the interactivity. The culture is moved by commodity and entertainment relationships, hollywoodianly gestated and designed to capture the attention and desire, and simultaneously, to direct them 
toward the consumption, no longer of goods, but of access and inclusion into the only possible world.

In this context, the culture of new capitalism strengthens subjective and cognitive fluid, wavelike, open, mutant, flexible and self-deforming modalities, which spread (in the school, family and work) associated with power devices operating in the short term. Thus, the illusion that experience is entertainment perhaps functions as a password for access to the identities that Rolnik (1997) termed the prêt-à-porter, following ephemeral, disposable identity models, which are always linked to the proposals and the interests of the market.

One question that emerges is how this logic of the mutations of capitalism reflects in the formation of teachers. We can ask in what sense such mutations of capitalism influence the ways of thinking, acting and feeling. Costa (2007) helps to reflect about these issues when he points out three aspects of education and of the subjectification processes in the contemporary world:

Firstly, I would say that the formation and education of individuals [...] are not immune to this increasing hyperaceleration and virtualization of our societies and our reality. [...] Secondly, [...] the practices and educational theorizations, considered critical, are currently found to be lost or confused in the face of these transformations that we are passing through. Thirdly, I believe that a considerable part of this disorientation and perplexity, which affect the practical and theoretical domains of education, is because of this insistence $[. .$.$] in dealing with an image$ of thought, the dialectic, unable [...] to support the complex and multifaceted relationships between the virtual and the actual. (p. 19)

Costa (2007) affirms that education does not know what to do with the flows and movements produced by so-called new capitalism, because it is only able to capture what is already defined and instituted, and also because it is used to understanding the reality from contradictions that generate dichotomies of the type learns-does not learn, knows-does not know, included-excluded, among others. The modern legacy of capital and, more recently, the connectionist legacy that marks current capitalism, concerns developing and empowering children, youths and adults, methodically intervening in the evolutionary steps to transform them into entrepreneurial beings, ready to face a world that works rapidly and in the short-term, in a regime of constant incompleteness, finally transforming empowerment into consumption.

The mutations of capitalism resonate in the field of teacher formation, generating cognition policies. The culture of new capitalism traversing the field of formation and education makes a cognition policy of (in)formation emerge in a dominant way (Dias, 2011). This reveals relationships of subjection to the changes of the capital, through a program that imprints forms of control expressed in continued evaluation, in permanent training and in the introduction of the logic of the company into all levels of schooling. Conversely, and adopting a different way of inhabiting the territory of the formation, the policies of the cognition of (trans) formation will be evidenced (Dias, 2011). These are affirmed approaching knowledge and invention and, at the same time, refusing the belief in a given subject and world. A policy of cognition as (trans)formation produces an expansion of the notion of cognition and highlights its inseparability from the idea of creation. The production of knowledge is not founded in a previous cognitive subject nor in a given supposed world but configures, in a pragmatic and reciprocal way, the self and the cognitive domain. Without invariant foundations, a cognition policy of (trans)formation specifically forges subjectivities and worlds (Dias, 2011).

\section{Skills Society Accelerated Modeling in the Formation of Teachers}

As previously mentioned, the skills society invests in the construction of portable abilities (Sennett, 2006). These skills emphasize the ability to work on several problems at the same time, with a wide range of constantly changing factors. The skills society seeks people who solve problems quickly and successfully. In the terms that we adopt, it seeks creative professionals. The cognitive policy is not inventive, as it does not value the invention of problems, but is focused on flexibility, consumption and the short-term.

The emphasis is on meritocratic logic that quantifies and values the creative and flexible subjectivities. It values the portable ability to process and interpret a range of information and carry out practices in permanent change. Sennett argues that the companies and consumption patterns have changed in the current society, but these changes have not liberated people. Science and technology have become productive forces of the capital. Conversely, access to information determines the degree of extension of the power and control of the subjectivities. Faced with this scenario, there is a need to identify the coercion techniques in play.

The culture of new capitalism requires us to always be plugged in, connected and included. It therefore produces a logic of empowerment that, according to Deleuze (1992), keeps the adults in a state of continual indebtedness, always in debt to the proliferation of information. Sennett (2006) asserts that the skills society is less interested in acquired knowing and more attentive to how much one is able to learn. The investment is then displaced from what is already known to what can be innovated. The production of subjectivity in such a society is marked by flexibility, contaminating other spheres of life. Indeed, while the skills society engenders modes of control, it extends and penetrates into the educational institutions, directly affecting the formation of teachers.

In the new capitalism companies, the thing that draws most attention is the absence of the long-term. The price of survival in the current world of work resides in the permanent motivation of the companies and their workers not to 
fixate on roles and, at the same time, in the ability to never do the same thing the way it was done before. That is, the value of a career is linked to the ability of solving short-term problems successfully and always in a new way. The ideas of novelty and success are close to what Sternberg (2000) proposes with his concept of successful intelligence, which is in line with the needs of new capitalism. Successful intelligence considers all the components of a problem to solve it creatively and rapidly. The development of skills and abilities ensures the speed and successful character of the performance. We realize that the notion of successful intelligence of Sternberg is in line with the notion of portable potential adaptation of Sennett (2006), in that both are defined by the ability to flexibly and successfully solve problems.

For Sternberg $(1990,1977)$ the concept of competence is defined by the logic of the information processing and involves at least one person, a task and a situation. According to Sternberg (1990), while performance signifies how a person does something, competence refers to how that person is perceived by themselves and by others. Competence defines the performance and encompasses intelligence, the intellectual style and motivation. Intelligence and its styles involve the analytical, creative and practical dimensions. Sternberg emphasizes that the prototype of scholastic competence has overvalued the analytical dimension, to the detriment of the practical and the creative, evaluating the students who are effective in the results of tests as competent. Even with this critical stance toward the traditional school, the work of Sternberg is characterized by the very limited comprehension of cognition, clinging to the performative logic of the intelligence and the efficiency to deal with the so-called "real world".

While the notion of competence refers to what the so called real world requires as intellectual performance, skill is defined as the ability to successfully perform the problem solving process. Cognitive skills are acquired and can be trained to generate competences that produce entrepreneurial performance in life and in the school. Thus, one must be aware of the types of labels that are expected and accepted in the world today, as well as their effects on the field of teacher formation. The focus on the competences can not stop us from thinking about the curriculum, its transmission, and principally the power relationships involved in it (Garcia \& Moreira, 2003; Macedo, 2000, 2002).

To define knowledge in terms of skills and competencies can result in a reductionist logic in relation to the formation curricula, where knowledge is measured by performing tasks. Understanding knowledge as the problem solving process, it would be the role of the curriculum to define the competencies and skills expected at the end of a schooling stage. With this way of conceiving the knowing, some malleability can be sought for the concept of competence, eventually believing it would indicate a valid pathway to transform the teaching. However, it should be noted that apparently neutral concepts such as information processing, competences and abilities actually arise in the institutional school life linked to ways of knowing and teaching. There is a need to perceive how these concepts carry with them relationships of knowledge and power. Ultimately, it is necessary to investigate the pedagogical and political effects that such notions may favor.

In the regime of new capitalism and in the work context, the notion of career associated with patterns of behavior and long-term investment has lost strength. A world of independent tasks and provisional teams, associated with the imminent risk of being dismissed or relocated to another sector or city, impedes the construction of a personal history consistent and coherent with future planning. In this sense, work no longer offers the experience of travelling a pathway or of following a direction in life. Instead, the worker is required to rapidly process information to suit the flow of the accelerated changes. This idea runs counter to the notion of experience that Benjamin (1996) and Larrosa (2004) suggest, making it clear that in the culture of new capitalism experience loses ground to information, as this is best suited to the fragmentation of the institutions and to the short-term.

In this multifaceted context combining the formation, training and culture of new capitalism, Gadelha (2009) states that individuals and collectives are

endowed by new technologies and governance mechanisms that make their formation and their education [...] a kind of unrestrained competition, in which "progress" is measured by the accumulation of points [...] translated as productivity rates. And they are evaluated according to the investments that they are constantly induced to make to valorize themselves as small businesses in an increasingly competitive market. The new entrepreneur can no longer be characterized as passive [...], some say that he is no longer even active, but an investor, a kind of partner that invests his human capital in the company where he works. (p. 156)

Gadelha (2009) states that it is in this sense that a new discourse in the field of education, which seeks to make the individual micro-entrepreneurs into true entrepreneurs, has been disseminated. These individuals are proactive, innovative, creative, and flexible, with a sense of opportunity and a marked ability to provoke changes. Gadelha also states that this discourse is welcomed and celebrated in education both by progressive sectors and by conservative sectors, by private and public segments, by governmental and nongovernmental organizations.

For Sennett (2006), meritocracy refers to the process of evaluating talent and potential skill, which also affects the school (Costa, 2009). The meritocratic logic values the ability of individuals to learn to cope with the flow, in the accelerated transit from one theme to another, from one problem to another. Meritocracy qualifies and quantifies the talent by the way it moves in the knowledge-power network established by the current businesses. Sennett calls into question 
the way advances in the economic sectors happen, saying that growth has brought benefits for finance, technology, communications and merchandising. However, through these advancements a better quality of life has not been found:

The institutions inspire only weak loyalty, they diminish participation and mediation of commands, they breed low levels of informal trust and high levels of anxiety about uselessness. A shortened framework of institutional time lies at the heart of this social degradation; the cutting edge has capitalized on superficial human relations. This same shortened time framework has disoriented individuals in efforts to plan their life. (Sennett, 2006, p. 167)

This leads to the question of meritocracy, as expressed by entrepreneurial logic, and to the possibility of establishing a hierarchically differentiated society, where the status of each person is ultimately determined by the degree and quality of accumulated cognitive capital (Gadelha, 2009). However, it is necessary to emphasize that not only are society and individuals controlled by entrepreneurial logic, but the school itself and the formation are also affected by the action of this process, as Gadelha (2009) shows us:

For Dolz and Ollagnier (2004), the notion of competences is inserted into the "hit parade of pedagogic appellations”, despite the uncertainties surrounding its definition, the phenomena to which it refers and its eventual uses in the field of education. From my understanding, the challenge here would be to develop (arqueogenealogical) studies that evidence the articulation of this notion with new forms of government of individuals and collectives, instead of merely sticking to the studies that seek to support the scientificity or not of this concept, from a scientificistic, epistemological and/or cognitive perspective. (p. 182)

With the authors, we stress that the notion of competence, as well as that of skill, often refers to the measurement and comparison of cognitive components that have or do not have market value, which may or may not deserve to be the object of investment.

\section{Cognition Policies and Formation of Teachers}

As already stated, the distinction between cognitivism and approach of inventive cognition is not just a problem of an explanatory model, but configures two different cognitive policies.

Cognitivism is not just a theoretical problem but a political problem. It is one of the configurations that our cognition assumes. It does not rest in the pages of books, but inhabits us, and often in a silent way. The assumptions of the model of representation [...] are often so ingrained in us that they are confused with a natural attitude. [...] On the other hand, to approach knowledge and creation, to affirm that the action of knowing configures the subject and the object, the self and the world in a reciprocal and indivisible way, is not just to propose a new understanding of cognition. It is an invitation to adopt a certain way of being in the world, of inhabiting an existential territory and of putting oneself in the relationship of knowledge. [...] Taking this stance requires a shift, a reversal of naturalized attitude, which requires, in principle, an effort. However, it can become, with practice, an embodied attitude, configuring a new cognitive policy. (Kastrup et al., 2008, p. 8)

We asked: to what extent is it possible for a cognition policy in the formation of teachers as (trans)formation (Dias, 2011) to resist the hegemonic tendency of information? How can an existential cognition policy that distrusts the short-term, the flexible and the "new" ideal teaching learning models be promoted with the student? How can the student be more than a mere consumer of information, pressured to accomplish tasks and solve problems? We consider that there is a need to resist, affirming strengths and engendering provisional ways, for a formation based on inventive learning (Kastrup, 2005). There is openness and space for other time regimes, cognition policies and ways to subjectify (Rocha, 2007).

For a policy of (in)formation cognition, we learn to obtain and to transmit knowledge (Dias, 2011). Learning is comprehended as the solution of predetermined problems, which are often introduced by teachers. The learning process adheres to the ready forms and to the acquisition of information. In a policy of cognition as (trans)formation, learning assumes the meaning of differentiation and includes the experience of problematization. The learning process does not submit the findings and purposes, but makes the individual derive cognition, keeping its divergent operation accessible.

Learning is therefore making cognition differentiate permanently from itself, thereafter engendering new worlds. The policy of the invention is a policy of openness of the attention to unrecognized experiences and to the concept of becoming. The challenge for the implementation of this policy is to design practices that allow the triggering of processes of problematization that are not reduced to finding a solution. (Kastrup, 2005, p. 1282)

We asked: what pedagogical practice would be capable of producing a cognitive policy of invention, shifting the focus from information to problematization? One potent route is to show that knowing is not separate from politics. It is through the practice and experience of problematization that we cause a field of relationships of force to emerge. It is not sufficient to transmit new information, which will soon be substituted by other new information, the formation needs to be made a 
unique experience, which conserves its disruptive force. A policy of (trans)formation therefore involves the displacement of our recognitive attitude and demands from us a permanent struggle against the notion of knowledge as information.

As previously mentioned, the logic of the skills society imprints cognitive policies of (in)formation in the field of teacher formation, perpetuating a business mode of operation. In another direction, we emphasize that knowledge does not summarize intelligence and also does not identify mental processing, which would represent a pre-existing world. We propose forging cognition policies of (trans)formation in the field of teacher formation that are not limited to the acquisition of portable abilities. On this pathway there are no ready methods or foolproof didactics, but a quotidian invention of strategies and devices for teaching and learning.

The policy of cognition as (in)formation can be exemplified in a classroom where the teacher raises all the elements of a particular content, illustrating these factors as power point slides or overhead projector transparencies. Arriving in the classroom, the teacher follows the sequence of slides linearly, reading them one by one. If the students make questions, the teacher asks them to wait for the end of the presentation, which usually occurs when the class time also ends. It appears that a time for questioning was not planned. The teacher then indicates that the questions will remain for the next class. In the next class the teacher comes with another series of slides or exercises presenting certain content, and so on. The classes continue throughout the semester, always in the direction of transmission of content and of solving problems. This is the prototype of a teacher transmitting information.

This is not to deny the importance of the transmission, but to affirm the need to problematize its hegemony. We stress the need for teachers formed with other cognitive policies, as forming teachers with other policies is to create cognitive conditions of openness to that which is problematic and differential. It is the possibility of accepting the questions that appear and that pressure that which was prepared by the teacher. Therefore we asked: how to work so that the formation of teachers produces a cognitive policy of (trans)formation? What would a pedagogical practice appropriate to this kind of knowing be? What is finally intended is to produce students with a cognitive policy in which they keep alive inventive and amplified cognition. Policies of (trans)formation operate in an experiential, embodied way and are attuned to the understanding that "to know = to do = to be" (Varela, 1995). This cognitive policy is averse to taking learning as the adaptation or acquisition of skills and competencies.

With different policies inhabiting the cognitive field of teacher formation, we insist on the need for taking a decision. The inventive policies of (trans)formation problematize the representational model of formation with its merely technical orientation and conservative morals. From the concept of policies of cognition, the abstract and representational ways of teaching and learning lose their status of eternity and neutrality.
A teacher who assumes a cognitive policy of (trans)formation carefully prepares his class, studying, learning and thinking about the topic, the text and the context in which they will work. This teacher comes to the classroom with content that, at first, needs to be transmitted, however, additionally, brings to the class a series of problematizations that take the content from the sacred place of understanding and put it in an inventive production process. The teacher brings for the students the problems he himself raised when studying, tightening with them what is being transmitted. Therefore the knowledge circulates and leaves its recognitive dimension, being opened up to invention. The result is that the class is collectively composed, i.e., with what the teacher brings and what the students bring. Knowledge emerges from this experience.

In this context, the attention of the teacher faces a challenge: how to keep a problematic field alive and pulsating? It is to mix learning and unlearning in a complex experience. The meeting of teachers and students seeks to sustain the problematic field, welcoming the not-knowing found throughout the formation experience. Rocha (2007) helps in the construction of this idea when he says:

Education is a practice of thinking. However, unfortunately, we are subject to an education of the practice of intelligence, like everything else. Everything is for the use. What links education to invention? Ulpian says that the artist is not concerned with the conquest of the social field, with socialization or communication, but with the breaking of boundaries, with imprecision, with the rupture of the human in us, in short, with what makes one think. ( $\mathrm{p} 43$ )

A policy of (trans)formation defines a problematizing teacher, who questions the traditional notion of learning as a passage from not knowing to knowing, rejecting the idea that learning is a question of acquisition. Indeed, such a teacher engenders a field of potency and affirms the learning in the experience. "It is the experience of the act of thinking itself, it is immersion into the void of time, pulling from the chaos the forces, affections, and sensations that make it work" (Rocha, 2007, p. 42). What we call the policy of (trans)formation goes in the same direction that Rocha indicates as a formation with production of meaning from singular and plural encounters that recur, always differently, in every class. The attention of the teacher returns to the challenge of keeping alive the problematic field of a class. This policy deviates from the idea of a teacher who "knows", avoiding totalitarian categorizations of formation, of teaching, of learning.

Under a policy of (trans)formation the experience seeks to move away from the logic of the market, rejecting the entertainment-class. The policy of (trans)formation is a resistance to the commoditization of experience, problematizing the very notion of formation. Perhaps it is time to open up to the collective production in which enlarged and inventive 
cognition appears. The problematizing professor struggles daily to produce meaning and to support this function.

\section{Final Considerations}

The aim of this study was to discuss the problem of the formation of teachers in the context of new capitalism and the culture of the skills society. We sought to distinguish two trends: that guided by computational cognitivism and the other based on the approach of enaction and on the inventive learning concept. We critically analyzed the processes of teacher formation that are reduced to the acquisition of technical and scientific knowledge and of content or information, targeting only the development of skills and competencies. We emphasized that this approach brings with it the danger of reducing the formation to the acquisition of ready to be consumed knowledge. In another direction, we argued that the formation is an inventive process, which cannot be reduced to previously defined goals with a final result. We point out that the discussion regarding the formation should be expanded and the policies of cognition involved in teaching and learning taken into account. In this case, it is important to examine which cognitive policies are being produced. Is the cognitive attitude sought limited to performing tasks or is it developed as a cognitive problematization attitude? What teachers are we forming in the contemporaneity?

Throughout our study we proposed the distinction between training and forming teachers. Deviating from the logic of training, we affirmed that the shared experience between those forming and those formed is a fruitful pathway, to be followed in future experiments. In this study we focused on the theoretical and epistemological discussion of the inventive formation of teachers. However, the challenge posed by such ideas must be addressed in practical pedagogic experiments, accompanied by an investigative attitude and empirical studies to be developed in the future. In this way, we can better evaluate the exercise of thinking differently and also to form differently, which often involve the reinvention of our own ways of knowing and relating to the world, with us and with knowledge itself.

\section{References}

Benjamin, W. (1996). Obras escolhidas: Magia e técnica, arte e política (7a ed.). São Paulo, SP: Brasiliense.

Benjamin, W. (2002). Reflexões sobre a criança, o brinquedo e a educação. São Paulo, SP: Ed. 34.

Costa, S. S. G. (2007). Educação, políticas de subjetivação e sociedades de controle. In A. M. Machado, A. M. D. Fernandes, \& M. L. Rocha (Orgs.), Novos possíveis no encontro da psicologia com a educação (pp. 15-36). São Paulo, SP: Casa do Psicólogo.

Costa, S. S. G. (2009). Governamentalidade neoliberal, teoria do capital humano e empreendedorismo. Educação e Realidade, 34(2), 171-186.
Deleuze, G. (1992). Conversações (P. P. Pelbart, Trad.). Rio de Janeiro, RJ: Ed. 34.

Dias, R. O. (2011). Deslocamentos na formação de professores: Aprendizagens de adultos, experiência e políticas cognitivas. Rio de Janeiro, RJ: Lamparina.

Fodor, J. A. (1983). Representation: Philosophical essays on the foundations of cognitive science. Cambridge, MA: MIT Press.

Gadelha, S. (2009). Biopolítica governamentalidade e educação: Introdução e conexões, a partir de Michel Foucault. Belo Horizonte, MG: Autêntica.

Garcia, R. L., \& Moreira, A. F. B. (2003). Currículo na contemporaneidade: Incertezas e dasafios. São Paulo, SP: Cortez.

Guattari, F. (1981). Revolução molecular: Pulsações políticas do desejo. São Paulo, SP: Brasiliense.

Guilford, J. P. (1975). Traits of creativity. In P. E. Vernon (Ed.), Creativity: Selected readings (pp. 167-188). Harmondsworth, England: Penguin Books.

Kastrup, V. (1999). A invenção de si e do mundo: Uma introdução do tempo e do coletivo no estudo da cognição. Campinas, SP: Papirus.

Kastrup, V. (2001). Aprendizagem, arte e invenção. In D. Lins (Org.), Nietzsche e Deleuze: Pensamento nômade (pp. 207-223). Rio de Janeiro, RJ: Relume-Dumará.

Kastrup, V. (2005). Políticas cognitivas na formação do professor e o problema do devir-mestre. Educação e Sociedade, 26(93), 1273-1288. doi:10.1590/S0101-73302005000400010

Kastrup, V., Tedesco, S., \& Passos, E. (2008). Políticas da cognição. Porto Alegre, RS: Sulina.

Larrosa, J. (2004). Linguagem e educação depois de babel. Belo Horizonte, MG: Autêntica.

Lazzarato, M. (2006). As revoluções do capitalismo (L. Corsini, Trad.). Rio de Janeiro, RJ: Civilização Brasileira.

Macedo, E. (2000). Formação de professores e diretrizes curriculares nacionais: Para onde caminha a educação? Teias, 1(2), 7-19. Retrieved from http://www.periodicos. proped.pro.br/index.php?journal=revistateias\&page $=$ artic le\&op=viewFile\&path\%5B\%5D=29\&path\%5B\%5D=31

Macedo, E. (2002). Currículo e competência. In A. C. Lopes \& E. Macedo (Orgs.), Disciplinas e integração curricular: Histórias e políticas (pp. 113-143). Rio de Janeiro, RJ: DP\&A.

Maturana, H. R., \& Varela, F. J. (2002). A árvore do conhecimento: As bases biológicas da compreensão humana (2a ed.). São Paulo, SP: Palas Athena.

Passeti, E. (2002). Anarquismos e sociedade de controle. In M. Rago, L. B. L. Orlandi, \& A. Veiga-Neto (Orgs.), Imagens de Foucault e Deleuze: Ressonâncias nietzschianas (pp. 123-138). Rio de Janeiro, RJ: DP\&A.

Pelbart, P. P. (2003). A vida capital: Ensaios de biopolítica. São Paulo, SP: Iluminuras.

Piaget, J. (1978). A epistemologia genética (N. C. Caixeiro, Trad.). São Paulo, SP: Abril Cultural. 
Rifkin, J. (2001). A era do acesso: A transição de mercados convencionais para networks e o nascimento de uma nova economia (M. L. G. L. Rosa, Trad.). São Paulo, SP: Makron Books.

Rocha, M. L. (2007). A formação como acontecimento: Solidão, pensamento e autogestão. In A. M. Machado, A. M. D. Fernandes, \& M. L. Rocha (Orgs.), Novos possíveis no encontro da psicologia com a educação (pp. 37-48). São Paulo, SP: Casa do Psicólogo.

Rolnik, S. (1997). Toxicômanos de identidade: Subjetividade em tempo de globalização. In D. Lins (Org.), Cultura e subjetividade: Saberes nômades (pp. 19-24). Campinas, SP: Papirus.

Sennett, R. (2005). A corrosão do caráter: Consequências pessoais do trabalho no novo capitalismo (M. Santarrita, Trad., 10a ed.). Rio de Janeiro, RJ: Record.

Sennett, R. (2006). A cultura do novo capitalismo (C. Marques, Trad.). Rio de Janeiro, RJ: Record.

Sternberg, R. J. (1977). Intelligence, information processing and analogical reasoning: The componential analysis of human abilities. Hillsdale, NJ: Lawrence Erlbaum.

Sternberg, R. J. (1990). Prototypes of competence and incompetence. In R. J. Sternberg \& J. Kolligian, Jr (Eds.), Competence considered (pp. 117-146). Binghampton, NY: Vail-Ballou Press.

Sternberg, R. J. (2000). A inteligência para o sucesso pessoal: Como a inteligência prática e criativa determina o sucesso (C. M. F. Pimentel, Trad.). Rio de Janeiro, RJ: Campus.

Varela, F. J. (n.d.). Conhecer: As ciências cognitivas, tendências e perspectivas (M. T. Guerreiro, Trad.). Lisboa, Portugal: Instituto Piaget.

Varela, F. J. (1995). Sobre a competência ética (A. Mourão, Trad.). Lisboa, Portugal: Edições 70.

Rosimeri de Oliveira Dias is an Adjunct Professor of the Departamento de Educação of the Faculdade de Formação de Professores of the Universidade do Estado do Rio de Janeiro.

Virgínia Kastrup is an Associate Professor at Universidade Federal do Rio de Janeiro. National Council for Scientific and Technological Development (CNPq) Productivity in Research scholarship recipient.

Received: Nov. $4^{\text {th }} 2011$

$1^{\text {st }}$ Revision: Dec. 26 2011

Approved: Apr. $2^{\text {nd }} 2012$

How to cite this article:

Dias, R. O., \& Kastrup, V. (2013). Skills society and cognition policies in the formation of teachers. Paidéia (Ribeirão Preto), 23(55), 243-251. doi:10.1590/1982-43272355201312 


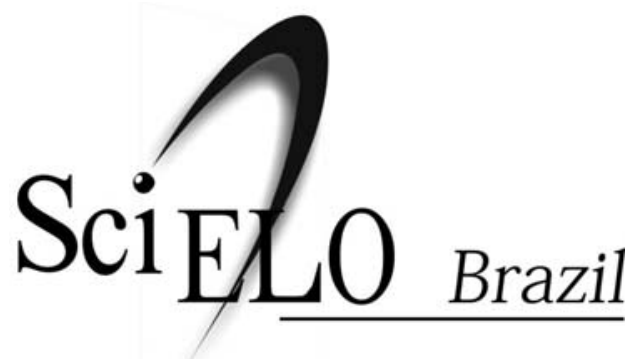

Paidéia (Ribeirão Preto) is a four-monthly publication available in full-text in the Scientific Electronic Library Online - SciELO.

The SciELO interface provides easy access to the tables of content and to the full-text articles.

The SciELO interface also provides the retrieval of articles by the author's name, the words from title, abstract and descriptors, in addition to providing bibliometric indicators and consultation indicators.

The articles are enriched with connections to the LILACS, MEDLINE and PubMed databases.

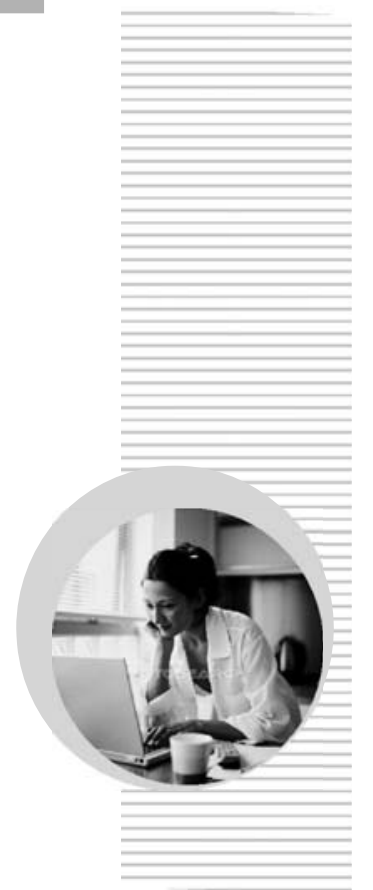

Paidéia (Ribeirão Preto) is a part of SciELO Brazil:

\section{www.scielo.br/paideia}

The SciELO interface provides access to a network of SciELO websites, gathering the major scientific journals of Latin America, Caribbean, Spain, Portugal and South Africa:

\section{www.scielo.org}

The electronic library is a project developed by the São Paulo Research Fundation (FAPESP), in partnership with the Latin American and Caribbean Center on Health Sciences Information (BIREME) and the National Council for Scientific and Technological Development (CNPq). 